Bull. Fac .Agric., Cairo Univ. 66:277-287(2015).

\title{
EFFECT OF SUNFLOWER RESIDUES UNDER DIFFERENT NITROGEN LEVELS ON WHEAT AND ITS ASSOCIATED WEEDS
}

\author{
(Received: 17 .11.2015)
}

\author{
By \\ I.E. Soliman and A. M. Hamza* \\ Weed Research Center Laboratory, Agriculture Research Center, Giza, Egypt. \\ *Pesticides Department, Faculty of Agriculture, Kafrelsheikh Universty, , Egypt.
}

\begin{abstract}
Two field experiments were conducted during the two successive seasons of 2013/2014 and 2014/2015, at Sakha Agricultural Research Station , Egypt, to study the allelopathic effects of sunflower residues (roots, stems, roots + stems, herbicide and control), under three nitrogen levels $(65,75$ and $85 \mathrm{~kg} \mathrm{~N} / \mathrm{fed})$ on wheat growth, grain yield and its components, as well as growth of weeds.

The results indicated that herbicide treatment and soil incorporation of sunflower roots, stems and roots + stems markedly decreased the number, fresh and dry weights of grassy, broadleaved and total weeds $/ \mathrm{m}^{2}$ at 70 days after sowing, compared with the control treatment in the two seasons. Increasing nitrogen rate substantially suppressed weed density, as well as the fresh and dry weights of total weeds in both seasons.Sunflower residues (roots, stems and roots + stems) and herbicide treatment significantly increased dry matter accumulation of wheat $/ \mathrm{m}^{2}$, LAI, CGR, NAR, number of spikes $/ \mathrm{m}^{2}$, spike length, (number of spikelets and grains/spike in the second season, only), 1000- grain weight, as well as grain and straw yields/fed, compared to the control treatment. In general, soil incorporation of sunflower roots or herbicide, being insignificant, resulted in the highest values with respect to most growth, grain yield and its attributes. Increasing nitrogen rate up to $85 \mathrm{~kg} \mathrm{~N} / \mathrm{fed}$, significantly increased dry matter accumulation of wheat $/ \mathrm{m}^{2}$, LAI, CGR, wheat plant height at harvest, number of spikes $/ \mathrm{m}^{2}$, (spike length and 1000- grain weight in the 1 st season, only), (number of spikelets and grains/spike in the second season, only), as well as grain and straw yields/fed. Whereas, it did not significantly affect NAR. There was no significant difference between 75 and $85 \mathrm{~kg} \mathrm{~N} /$ fed in most cases. It may be concluded that sunflower is a potential allelopathic crop and its allelopathic nature has more suppressive effects on weeds than wheat. Also data indicated that soil incorporation of sunflower roots, (roots + stems) or herbicide treatment, with $75 \mathrm{~kg} \mathrm{~N} / \mathrm{fed}$, produced similar grain yield/fed. It can be concluded that soil incorporation of sunflower roots with $75 \mathrm{~kg} \mathrm{~N} /$ fed could be recommended for optimum wheat grain yield under the environmental condition of this study, in addition to minimizing the environmental pollution caused by herbicides.
\end{abstract}

Key words: Sunflower residues, Nitrogen, Wheat, Weeds.

\section{INTRODUCTION}

One of the most serious problems of modern agriculture is crop losses caused by weeds. Worldwide, $10 \%$ loss of agricultural production is caused by weeds alone (Altieri and Liebman, 1998). Controlling weeds through allelopathy is one focal point for researchers working to sustain the world's food supply for future generations. Allelopathic potential can be utilized for weed control through four ways; namely, plant associated allelopathic plants to provide weed 
control, use of allelopathic plants in crop rotation and obtain allelopathic activity from plant residues in soil, identify and isolate potent allelochemicals and use these as herbicides and optimize the allelopathic potential in the crop by developing allelopathic cultivars (Duck, 1985).

In recent years, it has become also, evident that a large number of compounds extracted from weeds and crops significantly were toxic to living cell and organisms. Park and Moody (1991 and Mehboob et al., 2000) indicated that sunflower (Helianthus annuus L.),among several crops, exhibits a strong allelopathic property. Naseem (1997) reported that the incorporation of whole sunflower plants or (roots + leaves) showed more suppressive effect on weed density and dry matter accumulation. He also stated that the density and growth of weeds were less in wheat grown with fertilizer than wheat grown without fertilizer.Also,the effects of sunflower residue treatments on grain yield and its components of wheat ranged from stimulatory to inhibitory and the incorporation of sunflower roots with fertilizer increased the wheat grain yield and its components.

Mushtaq et al. (2010) revealed that (sorghum + sunflower) extracts combined with $1 / 4$ th $(75 \%$ less $)$ of label rates of herbicides inhibited dry matter production of wild oat by up to $89 \%$ and canary grass by up to $92 \%$. Mahmood et al. (2010) found that (sorghum + sunflower) water extract combination at higher concentration (100\%), completely inhibited the germination of horse purslane. In crux, combination of (sorghum + sunflower) water extracts may be used as natural herbicide to control horse purslane. Kaczmarek (2009) reported that allelochemicals are released by crop plants through leachation, decomposition, volatilization, and root exudates. In the future, allelopathy will play an important role in weed control and crop productivity. The allelopathic compounds can be used as natural herbicides and pesticides. Muhammad et al. (2009) showed that the application of sorghum and sunflower extracts at $12 \mathrm{~L} /$ ha each was more effective than other combinations. This treatment reduced wild oat dry matter by 42 -
$62 \%$, and canary grass by $36-55 \%$. Application of sorghum and sunflower at $6 \mathrm{~L}$ ha each increased the wheat grain yield by $89 \%$ during the first year, and by $35 \%$ during the second year. Tehmina and Rukhsana (2007) mentioned that sunflower leaf extracts allelochemicals showed substantial potential to be used as natural herbicide for broadleaved weeds such as $(C$. album), but the highest tested concentration successfully killed the weed and overcame weed crop competition and consequently increased wheat yield significantly.

Castillo (2005) indicated that Sunflower showed the greatest inhibitory action of Eleusine indica, Portulaca oleracea), Parthenium hysterophorus, Sorghum halepense) and Cyperus rotundus). These results support the use of these crop plants within a weed management program, in order to reduce weed populations without chemical herbicides. Azania et al. (2003) revealed that Several allelochemicals inhibit the seed germination and seedling growth of Amaranthus albus Amaranthus viridis, Agropyron repens, Elymus repens, Ambrosia artemisiifolia, Avena fatua,Celosia cristata, C. argentea var.,Chenopodium album, Chloris Barbara, Cynodon dactylon, Digitaria sanguinalis, Dactyloctenium aegyptium, Digitaria ciliaris, Echinochloa crus-galli, Flaveria australasica, Parthenium hysterophorus, Portulaca oleracea, Sida spinosa, Trianthema portulacastrum and Veronica persica. The inhibitory effects of this crop may be used for weed management to attain reduced herbicide use for sustainable agriculture.

Nitrogen fertilization is very important for plant growth and final grain yield of wheat and it should be applied at the optimum rate to meet the crop need ( Latiri et al., 1998; Sorour et al., 1998 and Sharshar et al., 2000). Increasing wheat growth by application of higher rates of nitrogen might, also, increase the growth of wheat - associated weeds.

The main objective of this study was to investigate the allelopathic effect of soil amended with sunflower plant materials on wheat and its associated weeds under different nitrogen levels. 


\section{MATERIALS AND METHODS}

Two field experiments were conducted during the successive seasons of 2014/2015 and 2015/2016 , at Sakha Agricultureal Research station, Egypt, to study the allelopathic effects of sunflower residues under different nitrogen rates on growth, grain yield and its components of wheat, as well as growth of weeds. The soil of the experimental field was clay in texture with $\mathrm{PH}$ value of 8.14 and contains $1.25 \%$ organic matter 16.5 , 9.35 and $279 \mathrm{ppm}$ available $\mathrm{N}, \mathrm{P}$ and $\mathrm{K}$, respectively ( mean of the two seasons for the upper $30 \mathrm{~cm}$ of soil). Seeds of sunflower "Sakha 53" were sown in the second week of June in 2013 and 2014 seasons. However, maize was sown in plots of treatments, not containing roots of sunflower. All cultural practices for both summer crops were done as recommended in the area. Sunflower plants were uprooted after harvest of heads. The uprooted plants were transported and air dried for ten days, then, they were manually separated into stems and roots. Stems were weighed to determine the weight of dry stems per unit area and chopped into small pieces (1-5 cm long) by an electric fodder cutter. The chopped-sunflower stems were incorporated into the respective plots with the help of a rotator according to the treatments.

The experimental design was a split plot, with four replications. The horizontal plots were assigned to the five treatments of sunflower residues, as given in Table (1), whereas, the vertical plots included the three nitrogen levels $(65,75$ and $85 \mathrm{~kg} \mathrm{~N} / \mathrm{fed})$. The nitrogen fertilizer in the form of Urea $(46 \%$ $\mathrm{N})$ was splitted into three additions $(1 / 5,2 / 5$ and $2 / 5$ applied at sowing and before the first and second irrigations of wheat, respectively).

The plot size was $21 \mathrm{~m}^{2}(3.5 \times 6 \mathrm{~m})$. The experimental soil was fertilized with $100 \mathrm{~kg}$ calcium superphosphate $\left(\begin{array}{lll}15.5 \% & \mathrm{P}_{2} \mathrm{O}_{5}\end{array}\right)$ per feddan during seed- bed preparation. Sowing of wheat took place on November the $25^{t h}$ and the $20^{\text {th }}$ in 2013/2014 and 2014/2015, respectively. Grains of wheat (Sakha cv.93) were mechanically drilled in rows, $12.5 \mathrm{~cm}$ apart, at a rate of $60 \mathrm{~kg} / \mathrm{fed}$. The other cultural practices were done as recommended.

Table (1): Treatments of sunflower residues.

\begin{tabular}{|c|c|c|c|}
\hline No. & Treatment & $\begin{array}{c}\text { Sunflower } \\
\text { residue }\end{array}$ & $\begin{array}{c}\text { Preceding } \\
\text { crop }\end{array}$ \\
\hline 1 & Control & No-residue & Maize \\
2 & Herbicide ( Panther) & No-residue & Maize \\
3 & Roots (R) & Roots & Sunflower \\
4 & Stems (S) & Stems & Maize \\
5 & Roots + stems (R+S) & Roots \& stems & Sunflower \\
& \multicolumn{3}{|l|}{} \\
\hline
\end{tabular}

\subsection{The collected data}

\subsubsection{Weeds}

At 70 days after sowing one square meter was randomly selected from each plot of wheat. Then, the number of grassy and broad-leaved weeds $/ \mathrm{m}^{2}$, as well as their fresh and dry weights $/ \mathrm{m}^{2}$ were determined. Weeds were air-dried, then oven dried to constant weight for 48 hour at $70 \mathrm{C}$. The percent ago of weed reduction $(\mathrm{R})$ was calculated using the following equation:

$\mathrm{R}=(\mathrm{A}-\mathrm{B} / \mathrm{A}) \times 100$

Where : $\mathrm{A}$ and $\mathrm{B}$ refer to dry weight of weeds in the untreated and treated plots, respectively.

\subsubsection{Wheat}

Two samples at 80 and 100 days after sowing were taken. Wheat plants in one meter area of two rows $(1 \times 0.25=0.25 \mathrm{~m} 2)$ from each plot, were randomly selected and wheat plants of the samples were carefully harvested at soil surface. The samples were separated into leaves (leaf blades), stems (stems + sheaths) and spikes. Dry matter accumulation per unit area was recorded. Leaf area index (LAI), crop growth rate (CGR) in $\mathrm{g} / \mathrm{m}^{2} /$ week and net assimilation rate (NAR) in $\mathrm{g} / \mathrm{m}^{2} /$ week were computed, according to Watson (1952), as follows:

LAI = unit of leaf area per plant of sample/ground area of sample.

$\mathrm{CGR}=\left(\mathrm{W}_{2}-\mathrm{W}_{1}\right) /\left(\mathrm{t}_{2}-\mathrm{t}_{1}\right)$

$\mathrm{NAR}=\left(\mathrm{W}_{2}-\mathrm{W}_{1}\right)\left(\ln A_{2}-\ln \mathrm{A}_{1}\right) /$

$$
\left(\mathrm{A}_{2}-\mathrm{A}_{1}\right)\left(\mathrm{t}_{2}-\mathrm{t}_{1}\right)
$$

Where: $\mathrm{W}_{1}, \mathrm{~A}_{1}$ and $\mathrm{W}_{2}, A_{2}$, respectively, refer to dry weight and leaf area at time $t_{1}$ 
and $t_{2}$ in weeks.

At harvest, plant height and the number of spikes/ $\mathrm{m}^{2}$ were measured and ten spikes were randomly selected from each plot to determine spike length,the number of spikelets/spike,the number and weight of grains/spike and 1000- grain weight. The straw yield (ton/fed) and grain yield (ardab/fed) were determined at harvest from yield the central area of $12 \mathrm{~m} 2(2 \times 6)$ from each plot.

\subsubsection{Statistical analysis:}

The analysis of variance was carried out according to Gomez and Gomez (1984). Treatment means were compared by Duncan's multiple range test (Duncan, 1955). All statistical analysis was performed, using the analysis of variance technique by means of "IRRISTAT" computer software package.

\section{RESULTES AND DISCUSSION}

3.1.Effect of sunflower residues and nitrogen levels on

\subsubsection{Weeds}

The most dominant weeds were: in wheat field (Phalaris minor Retz., Phalaris paradoxa L., Polypogon monspeliensis L. and Lolium temulentum L. as grassy weeds and (Vicia sativa L., Melilotus indicus All., Melilotus siculus All., Medicago hispida Gaerth., Beta vulgaris L.) and (Rumex dentatus, L.) as broad-leaved weeds in both 2013/2014 and 2014/2015 seasons.

The effect of sunflower residues was significant on the number, fresh and dry weights of grassy, broad-leaved and total weeds $/ \mathrm{m}^{2}$ in both seasons (Tables 2 and 3 ). Herbicide treatment and soil incorporation of sunflower (roots, stems and roots + stems) markedly decreased the number, fresh and dry weights of grassy, broad-leaved and total weeds $/ \mathrm{m}^{2}$, compared to the control treatment in the two seasons. Herbicide and sunflower $(\mathrm{R}+\mathrm{S})$ treatments gave the best results in controlling weeds. Soil incorporation of sunflower residues $(\mathrm{R}, \mathrm{S}$ and $\mathrm{R}+\mathrm{S})$ and herbicide treatment reduced the dry weight

Table (2): Number of weeds $/ \mathrm{m}^{2}$ at 70 days after sowing as affected by sunflower residues and nitrogen rates in $2013 / 2014$ and $2014 / 2015$ seasons.

\begin{tabular}{|c|c|c|c|c|c|c|c|c|}
\hline \multirow[b]{2}{*}{ Factors } & \multicolumn{4}{|c|}{$2013 / 2014$ season } & \multicolumn{4}{|c|}{$2014 / 2015$ season } \\
\hline & $\begin{array}{l}\text { Grassy } \\
\text { weeds }\end{array}$ & $\begin{array}{l}\text { Broad- } \\
\text { leaved } \\
\text { weeds }\end{array}$ & $\begin{array}{c}\text { Total } \\
\text { weeds }\end{array}$ & $\begin{array}{c}\text { Reduction } \\
\%\end{array}$ & $\begin{array}{c}\text { Grassy } \\
\text { weeds }\end{array}$ & $\begin{array}{l}\text { Broad- } \\
\text { leaved } \\
\text { weeds }\end{array}$ & $\begin{array}{c}\text { Total } \\
\text { weeds }\end{array}$ & $\begin{array}{c}\text { Reduction } \\
\%\end{array}$ \\
\hline & \multicolumn{8}{|c|}{ Number of weeds / m2 } \\
\hline Residue: & * & * & * & & * & * & * & \\
\hline Control & $101.6 \mathrm{a}$ & $82.4 \mathrm{a}$ & $184.0 \mathrm{a}$ & & $85.7 \mathrm{a}$ & $90.5 \mathrm{a}$ & $176.2 \mathrm{a}$ & \\
\hline Herbicide & $28.7 \mathrm{c}$ & $18.2 d$ & $46.9 \mathrm{c}$ & 74.51 & $24.9 \mathrm{~d}$ & $14.0 \mathrm{c}$ & $38.9 \mathrm{c}$ & 77.92 \\
\hline Roots $(\mathbf{R})$ & $45.0 \mathrm{be}$ & $32.4 \mathrm{be}$ & $77.4 \mathrm{~b}$ & 57.93 & 37.6be & $22.4 \mathrm{be}$ & $62.0 \mathrm{be}$ & 64.81 \\
\hline Stem $(\mathbf{S})$ & $51.3 \mathrm{~b}$ & $33.9 \mathrm{~b}$ & $85.2 \mathrm{~b}$ & 53.69 & $48.1 \mathrm{~b}$ & $29.3 b$ & $77.4 \mathrm{~b}$ & 56.07 \\
\hline $\mathbf{R}+\mathbf{S}$ & $37.8 \mathrm{be}$ & $24.9 \mathrm{~cd}$ & $62.7 \mathrm{be}$ & 65.92 & $33.9 \mathrm{~cd}$ & $16.4 \mathrm{c}$ & $50.3 \mathrm{c}$ & 71.45 \\
\hline Kg N/fed.: & NS & $*$ & $*$ & & $*$ & $*$ & $*$ & \\
\hline 65 & $61.9 \mathrm{a}$ & $38.3 \mathrm{a}$ & $100.2 \mathrm{a}$ & & $51.9 \mathrm{a}$ & $48.1 \mathrm{a}$ & $100.0 \mathrm{a}$ & \\
\hline 75 & $51.8 \mathrm{ab}$ & $31.7 \mathrm{~b}$ & $83.5 \mathrm{ab}$ & 16.66 & $44.3 \mathrm{ab}$ & $32.0 \mathrm{~b}$ & $76.3 b$ & 23.70 \\
\hline 85 & $43.5 b$ & $28.4 \mathrm{~b}$ & $71.9 \mathrm{~b}$ & 28.24 & $41.7 b$ & $21.6 b$ & $63.3 \mathrm{c}$ & 36.70 \\
\hline Interaction: & NS & NS & NS & & NS & NS & NS & \\
\hline
\end{tabular}


Effect of sunflower residues under different nitrogen levels

Table (3): Fresh and dry weights of weeds $\left(\mathrm{g} / \mathrm{m}^{2}\right)$ at 70 days after sowing as affected by sunflower residues and nitrogen rates in 2013/2014 and 2014/2015 seasons.

\begin{tabular}{|c|c|c|c|c|c|c|c|c|}
\hline & \multicolumn{4}{|c|}{$2013 / 2014$ season } & \multicolumn{4}{|c|}{$2014 / 2015$ season } \\
\hline Factors & $\begin{array}{c}\text { Grassy } \\
\text { weeds }\end{array}$ & $\begin{array}{l}\text { Broad- } \\
\text { leaved } \\
\text { weeds }\end{array}$ & Total weeds & $\begin{array}{c}\text { Reduction } \\
\%\end{array}$ & $\begin{array}{l}\text { Grassy } \\
\text { weeds }\end{array}$ & $\begin{array}{l}\text { Broad- } \\
\text { leaved } \\
\text { weeds }\end{array}$ & $\begin{array}{l}\text { Total } \\
\text { weeds }\end{array}$ & $\begin{array}{c}\text { Reduction } \\
\%\end{array}$ \\
\hline & \multicolumn{8}{|c|}{ Fresh weight $\left(\mathrm{g} / \mathrm{m}^{2}\right)$} \\
\hline Residue: & $*$ & $*$ & $*$ & & $*$ & $*$ & $*$ & \\
\hline Control & $386.4 \mathrm{a}$ & $366.2 \mathrm{a}$ & $752.6 \mathrm{a}$ & & $357.6 \mathrm{a}$ & $355.5 \mathrm{a}$ & $713.1 \mathrm{a}$ & \\
\hline Herbicide & $62.8 \mathrm{~d}$ & $79.6 \mathrm{c}$ & $142.4 \mathrm{c}$ & 81.07 & $88.4 \mathrm{~d}$ & $21.2 \mathrm{~d}$ & $109.6 \mathrm{~d}$ & 84.63 \\
\hline Roots (R) & $128.2 \mathrm{~b}$ & $161.6 \mathrm{~b}$ & $289.8 \mathrm{~b}$ & 61.49 & 156.3 be & $85.1 \mathrm{c}$ & $241.4 \mathrm{~b}$ & 66.14 \\
\hline Stem (S) & $137.6 \mathrm{~b}$ & $165.2 \mathrm{~b}$ & $312.8 \mathrm{~b}$ & 58.43 & $214.9 \mathrm{~b}$ & $147.1 \mathrm{~b}$ & $362.0 \mathrm{~b}$ & 49.23 \\
\hline $\mathbf{R}+\mathbf{S}$ & $96.8 \mathrm{c}$ & 125.2 be & $222.0 \mathrm{c}$ & 70.50 & $135.5 \mathrm{c}$ & $49.5 \mathrm{~cd}$ & $185.0 \mathrm{~cd}$ & 74.05 \\
\hline Kg N/fed: & NS & $*$ & $*$ & & $*$ & $*$ & $*$ & \\
\hline 65 & 171.4 & $198.5 \mathrm{a}$ & $370.0 \mathrm{a}$ & & $229.9 \mathrm{a}$ & $187.4 \mathrm{a}$ & $417.3 \mathrm{a}$ & \\
\hline 75 & 137.6 & $144.9 \mathrm{~b}$ & $282.5 \mathrm{~b}$ & 23.64 & $161.5 b$ & $124.9 \mathrm{~b}$ & $296.4 \mathrm{~b}$ & 28.97 \\
\hline 85 & 116.8 & $129.7 \mathrm{~b}$ & $246.5 \mathrm{~b}$ & 33.37 & $170.2 \mathrm{~b}$ & $82.7 \mathrm{~b}$ & $252.9 \mathrm{~b}$ & 39.39 \\
\hline \multirow[t]{2}{*}{ Interaction: } & NS & NS & NS & & NS & NS & NS & \\
\hline & \multicolumn{8}{|c|}{ Dry weight $\left(\mathrm{g} / \mathrm{m}^{2}\right)$} \\
\hline Residue: & $* *$ & $*$ & $*$ & & $*$ & $*$ & $*$ & \\
\hline Control & $38.6 \mathrm{a}$ & $23.9 \mathrm{a}$ & $62.5 \mathrm{a}$ & & $28.1 \mathrm{a}$ & $30.1 \mathrm{a}$ & $58.2 \mathrm{a}$ & \\
\hline Herbicide & $4.3 \mathrm{~d}$ & $8.5 \mathrm{~b}$ & $12.8 \mathrm{~d}$ & 79.52 & $5.9 \mathrm{~d}$ & $2.9 \mathrm{~d}$ & $8.8 \mathrm{c}$ & 84.87 \\
\hline Roots (R) & 9.6 be & $12.6 \mathrm{~b}$ & 22.2 be & 64.48 & 12.9 be & 6.7 be & 19.6 be & 66.32 \\
\hline Stem (S) & $12.0 \mathrm{~b}$ & $13.9 \mathrm{~b}$ & $25.9 \mathrm{~b}$ & 58.56 & $17.3 \mathrm{~b}$ & $9.6 \mathrm{~b}$ & $26.9 \mathrm{~b}$ & 53.78 \\
\hline $\mathbf{R}+\mathbf{S}$ & $6.9 \mathrm{~cd}$ & $10.5 \mathrm{~b}$ & $17.4 \mathrm{~cd}$ & 72.16 & $10.3 \mathrm{~cd}$ & $3.2 \mathrm{~cd}$ & $13.5 \mathrm{bc}$ & 76.80 \\
\hline Kg N/fed: & NS & $*$ & $*$ & & NS & $*$ & $*$ & \\
\hline 65 & 13.3 & $17.0 \mathrm{a}$ & $30.3 \mathrm{a}$ & & 15.8 & $13.8 \mathrm{a}$ & $29.6 \mathrm{a}$ & \\
\hline 75 & 12.4 & $11.8 \mathrm{~b}$ & $24.2 \mathrm{~b}$ & 20.13 & 13.4 & $9.2 \mathrm{~b}$ & $22.6 \mathrm{~b}$ & 23.64 \\
\hline 85 & 12.3 & $11.2 \mathrm{~b}$ & $23.5 \mathrm{~b}$ & 22.44 & 14.3 & $5.7 \mathrm{~b}$ & $20.0 \mathrm{~b}$ & 32.43 \\
\hline Interaction: & NS & NS & NS & & NS & NS & NS & \\
\hline
\end{tabular}

*, ** and N.S. indicate $\mathrm{p}<0.05, \mathrm{p}<0.01$ and not significant, respectively. Means designated by the same letters are not significantly different at $5 \%$ level, using DMR test.

of total weeds by $64.84,58.56,72.16$ and $79.52 \%$ in the first season and by 66.32 , $53.78,76.80$ and $84.87 \%$ in the second season, as compared to the control treatment. This my be due to the release of allelochemicals from sunflower residues. This was in a line with the findings of Naseem (1997),who indicated that sunflower exhibited selective allelopathic effects on weed density and growth.

Increasing nitrogen rate decreased the number, fresh and dry weights of grassy, broad-leaved and total weeds $/ \mathrm{m}^{2}$ in both seasons, but the differences in fresh weight in the first season and in dry weight in the two seasons of grassy weeds did not reach the 5\% 
level of significant ( Tables 2 and 3 ). No significant differences were evidenced in these traits between 75 and $85 \mathrm{~kg} \mathrm{~N} / \mathrm{fed}$. Naseem (1997) reported similar effects for applied nitrogen fertilizer to wheat on weed population density and growth.

The interaction between sunflower residues and nitrogen rates had no significant effect on the number of grass, broadleaf and total weeds $/ \mathrm{m}^{2}$, as well as, on the fresh and dry weights of different weeds in both seasons (Tables 2 and 3 ).

\subsubsection{Wheat}

Sunflower residues [roots (R), stems (S) and $\mathrm{R}+\mathrm{S}]$ and herbicide treatment substantially increased the dry matter accumulation $\left(\mathrm{g} / \mathrm{m}^{2}\right)$, leaf area index (LAI), crop growth rate (CGR) and net assimilation rate (NAR) of wheat, compared to the control treatment at the tested growth stage in both seasons (Tables 4 and 5). Soil incorporation of sunflower roots or herbicide resulted in the largest values, with respect to these characters. This might be due to minimized weed competition and primitive effect of root allelopathic, both of which were sufficient to prevent plants from becoming increasingly badly placed in the population structure so that they might grow in a better environment and would probably had a better rate of dry matter accumulation per unit of ground area (CGR).

Table (4): Dry matter of wheat plants $(\mathrm{g} / \mathrm{m} 2)$ as affected by sunflower residues and nitrogen rates in 2013/ 2014 and 2014/ 2015 seasons.

\begin{tabular}{|c|c|c|c|c|}
\hline \multirow{3}{*}{ Factor } & \multicolumn{4}{|c|}{ Days from sowing } \\
\hline & 80 & 100 & 80 & 100 \\
\hline & \multicolumn{2}{|c|}{$2013 / 2014$} & \multicolumn{2}{|c|}{$2014 / 2015$} \\
\hline Residue: & $*$ & $* *$ & $* *$ & $* *$ \\
\hline Control & $256.8 \mathrm{~b}$ & $433.2 \mathrm{~b}$ & $289.3 \mathrm{c}$ & $444.0 \mathrm{~d}$ \\
\hline Herbicide & $339.0 \mathrm{a}$ & $682.6 \mathrm{a}$ & $365.0 \mathrm{ab}$ & $739.1 \mathrm{a}$ \\
\hline Roots (R) & $328.0 \mathrm{a}$ & $679.8 \mathrm{a}$ & $393.8 \mathrm{a}$ & $738.4 \mathrm{a}$ \\
\hline Stem $(\mathbf{S})$ & $300.7 \mathrm{a}$ & $603.1 \mathrm{a}$ & $352.2 \mathrm{~b}$ & $608.7 \mathrm{c}$ \\
\hline $\mathbf{R}+\mathbf{S}$ & $348.4 \mathrm{a}$ & $664.1 \mathrm{a}$ & $362.9 \mathrm{~b}$ & $674.8 \mathrm{~b}$ \\
\hline Kg N/fed: & * & $*$ & ** & $* *$ \\
\hline 65 & $261.1 \mathrm{~b}$ & $542.5 \mathrm{~b}$ & $295.9 \mathrm{~b}$ & $552.6 \mathrm{c}$ \\
\hline 75 & $332.6 \mathrm{a}$ & $630.4 \mathrm{a}$ & $366.0 \mathrm{a}$ & $661.9 \mathrm{~b}$ \\
\hline 85 & $349.9 \mathrm{a}$ & $664.9 \mathrm{a}$ & $396.1 \mathrm{a}$ & $708.5 \mathrm{a}$ \\
\hline Interaction & N.S & N.S & N.S & $* *$ \\
\hline
\end{tabular}

Increasing nitrogen rate from 65 to 85 $\mathrm{kg} / \mathrm{fed}$ caused a significant increase in the dry matter accumulation $\left(\mathrm{g} / \mathrm{m}^{2}\right)$ of wheat and LAI, in both seasons, and in CGR in the second season only, but it had no significant effect on NAR in the two seasons (Tables 4 and 5). The differences between 75 and $85 \mathrm{~kg}$ $\mathrm{N} /$ fed. did not reach the level of significance in all cases. Such favorable effect of nitrogen on the dry matter accumulation might have been resulted from increased photosynthetic area which resulted in more photosynthates production. These results are in harmony with those of Latiri et al. (1998) and Sorour et al. (1998).

The interaction between sunflower residues and nitrogen rates had a highly significant effect on dry matter accumulation $\left(\mathrm{g} / \mathrm{m}^{2}\right)$ of wheat, at 100 days from sowing (DAS) and on leaf area index at 80 DAS in the second season, only (Tables 4 and 5). Wheat grown with sunflower roots and $85 \mathrm{~kg} \mathrm{~N} / \mathrm{fed}$ accumulated more dry matter per unit area $\left(857.3 \mathrm{~g} / \mathrm{m}^{2}\right)$ than all other combination treatments. The highest leaf area index (3.90) was obtained from wheat received $75 \mathrm{~kg}$ $\mathrm{N} /$ fed plus sunflower roots or herbicide. Wheat plants grown with sunflower roots and 75 or $85 \mathrm{~kg} \mathrm{~N} / \mathrm{fed}$. did not significantly differ in LAI (Table 5).

Sunflower residue treatments significantly influenced wheat plant height at harvest, the number of spikes $/ \mathrm{m}^{2}$, spike length, 1000 grain weight and straw and grain yields/fed in both seasons, as well as the number of spikelets and grains/spike in the second season, only (Tables 7 and 8). Plant height, grain yield and its attributes and straw yield of wheat were significantly higher in plots where $(R)$ or $(R+S)$ of sunflower were added than those of the control. No significant differences in most of these characteristics were observed in plots that contained sunflower roots, compared to the herbicide plots. However, all sunflower residue and herbicide treatments produced significantly higher plant height, number of spikes $/ \mathrm{m}^{2}$, spike length, 1000grain weight and grain yield/fed in the two 
Table (5): Leaf area index (LAI), crop growth rate (CGR) and net assimilation rate (NAR) as affected by sunflower residues and nitrogen rates in 2013 / 2014 and 2014 / 2015 seasons.

\begin{tabular}{|c|c|c|c|c|c|c|c|c|}
\hline \multirow{4}{*}{ Factor } & \multicolumn{8}{|c|}{ Days from sowing } \\
\hline & 80 & 100 & 80 & 100 & \multirow{2}{*}{\multicolumn{2}{|c|}{$\frac{80-100}{\text { CGR g/m²/week) }}$}} & \multirow{2}{*}{\multicolumn{2}{|c|}{$\begin{array}{c}80-100 \\
\text { NAR }\left(\mathrm{g} / \mathrm{m}^{2} / \text { week }\right)\end{array}$}} \\
\hline & \multicolumn{4}{|c|}{ LAI } & & & & \\
\hline & \multicolumn{2}{|c|}{$2013 / 2014$} & \multicolumn{2}{|c|}{$2014 / 2015$} & $2013 / 14$ & $2014 / 15$ & 2013/14 & $2014 / 15$ \\
\hline Residue: & $*$ & $* *$ & $* *$ & $* *$ & $*$ & $* *$ & $*$ & $* *$ \\
\hline Control & $2.58 \mathrm{c}$ & $3.32 \mathrm{~b}$ & $2.13 \mathrm{c}$ & $3.06 \mathrm{c}$ & $62.0 \mathrm{~b}$ & $54.0 \mathrm{~d}$ & $21.5 \mathrm{~b}$ & $20.9 \mathrm{c}$ \\
\hline Herbicide & $3.85 \mathrm{ab}$ & $5.49 \mathrm{a}$ & $3.15 \mathrm{ab}$ & $5.59 \mathrm{a}$ & $121.6 \mathrm{a}$ & $133.8 \mathrm{a}$ & $27.4 \mathrm{a}$ & $31.6 \mathrm{a}$ \\
\hline Roots $®$ & $3.74 \mathrm{ab}$ & $5.21 \mathrm{a}$ & $3.48 \mathrm{a}$ & $5.91 \mathrm{a}$ & $127.6 \mathrm{a}$ & $122.9 \mathrm{ab}$ & $28.8 \mathrm{a}$ & $25.4 \mathrm{~b}$ \\
\hline Stems (S) & 3.03 be & $4.71 \mathrm{a}$ & $2.93 \mathrm{~b}$ & $4.76 \mathrm{~b}$ & $110.4 \mathrm{a}$ & $91.5 \mathrm{c}$ & $26.9 \mathrm{a}$ & 22.6 be \\
\hline $\mathbf{R}+\mathbf{S}$ & $4.03 \mathrm{a}$ & $5.03 \mathrm{a}$ & $3.07 \mathrm{ab}$ & $5.69 \mathrm{a}$ & $113.3 \mathrm{a}$ & $112.9 \mathrm{~b}$ & $27.8 \mathrm{a}$ & $23.3 \mathrm{~b}$ \\
\hline Kg N/fed. : & $*$ & $* *$ & $*$ & $*$ & & $*$ & N.S & N.S \\
\hline 65 & $2.74 \mathrm{~b}$ & $3.93 \mathrm{~b}$ & 2.55 b 3 & $4.33 \mathrm{~b}$ & N.S 101.6 & $92.6 \mathrm{~b}$ & 30.7 & 24.1 \\
\hline 75 & $3.45 \mathrm{ab}$ & $4.90 \mathrm{a}$ & $3.12 \mathrm{a}$ & $5.20 \mathrm{a}$ & 107.7 & $103.0 \mathrm{ab}$ & 25.8 & 26.1 \\
\hline 85 & $4.01 \mathrm{a}$ & $5.41 \mathrm{a}$ & $3.11 \mathrm{a}$ & $5.51 \mathrm{a}$ & 112.0 & $113.1 \mathrm{a}$ & 25.0 & 26.7 \\
\hline Interaction & N.S & N.S & $*$ & N.S & N.S & N.S & N.S & N.S \\
\hline
\end{tabular}

Table (6): Dry matter accumulation $(\mathrm{g} / \mathrm{m} 2)$ and leaf area index of wheat as affected by the interaction between sunflower residues and nitrogen rates in 2014 / 2015 season.

\begin{tabular}{|c|c|c|c|c|c|}
\hline \multirow{2}{*}{$\begin{array}{c}\text { Kg } \\
\text { N/fed. }\end{array}$} & \multicolumn{5}{|c|}{ Residue } \\
\hline & Control & Herbicide & Roots (R) & Stems $(\mathbf{S})$ & $\mathbf{R}+\mathbf{S}$ \\
\hline \multirow[b]{2}{*}{65} & \multicolumn{5}{|c|}{ Dry matter accumulation $\left(\mathrm{g} / \mathrm{m}^{2}\right)$ at $100 \mathrm{DAS}$} \\
\hline & \multicolumn{2}{|r|}{716.3 bed } & $596.1 \mathrm{~g}$ & $510.8 \mathrm{~h}$ & $615.3 \mathrm{fg}$ \\
\hline 75 & $487.5 \mathrm{~h}$ & 731.9 be & $761.8 \mathrm{~b}$ & $650.7 \mathrm{efg}$ & $677.7 \mathrm{cde}$ \\
\hline 85 & $519.9 \mathrm{~h}$ & $768.9 \mathrm{~b}$ & $857.3 \mathrm{a}$ & 624.7 def & 731.5 be \\
\hline \multirow[b]{2}{*}{65} & \multicolumn{5}{|c|}{ Leaf area index at $80 \mathrm{DAS}$} \\
\hline & \multirow{3}{*}{$\begin{array}{l}1.82 \mathrm{~g} \\
2.01 \mathrm{fg} \\
2.48 \mathrm{ef}\end{array}$} & \multirow{3}{*}{$\begin{array}{c}2.72 \mathrm{de} \\
3.81 \mathrm{a} \\
2.82 \mathrm{cde}\end{array}$} & \multirow{3}{*}{$\begin{array}{c}3.02 \mathrm{~b}-\mathrm{e} \\
3.81 \mathrm{a} \\
3.48 \mathrm{ab}\end{array}$} & \multirow{3}{*}{$\begin{array}{l}2.73 \mathrm{de} \\
2.89 \mathrm{~b}-\mathrm{e} \\
2.14 \mathrm{bed}\end{array}$} & \multirow{3}{*}{$\begin{array}{l}2.74 \mathrm{de} \\
2.93 \mathrm{~b}-\mathrm{e} \\
3.27 \mathrm{abc}\end{array}$} \\
\hline 75 & & & & & \\
\hline 85 & & & & & \\
\hline
\end{tabular}

Means designated by the same letters are not significantly different at $5 \%$ level, using DMR test.

seasons, as well as the number of spikelets and grains/spike and straw yield in the second season, only than the control treatment.

More grain yield in the case of sunflower roots might be attributed to more fertile tillers (spikes/m2), spikelets and grains/spike and 1000 grain weight.These results are confirmed with the findings of Naseem (1997), who indicated that soil incorporation with roots of fertilized sunflower significantly recorded maximum plant height, maximum straw yield and higher grain yield and its attributes of wheat, compared to the control treatment.

Increasing nitrogen rates from 65 to 85 $\mathrm{kg} / \mathrm{fed}$ substantially increased plant height, the number of spikes $/ \mathrm{m}^{2}$, straw and grain yields/fed in both seasons, spike length, the number of grains/spike and 1000- grain weight in the first season, only), as well as the number of spikelets/spike (in the second season, only (Tables 7 and 8). With respect to plant height, spike length and the number of grains/spike, wheat plants received $75 \mathrm{~kg}$ $\mathrm{N} /$ fed did not practically differ from those 
Table (7): Plant height, straw yield, grain yield and its attributes of wheat as affected by sunflower residues and nitrogen rates in 2013 / 2014 season.

\begin{tabular}{|c|c|c|c|c|c|c|c|c|}
\hline Factor & $\begin{array}{c}\text { Plant } \\
\text { height } \\
\text { (cm) }\end{array}$ & $\begin{array}{c}\text { No. of } \\
\text { spikes/m2 }\end{array}$ & $\begin{array}{c}\text { Spike } \\
\text { length (cm) }\end{array}$ & $\begin{array}{c}\text { No. of } \\
\text { spikelets/ } \\
\text { spike }\end{array}$ & $\begin{array}{c}\text { No. of grains } \\
\text { /spike }\end{array}$ & $\begin{array}{c}\text { 1000-grain } \\
\text { weight (g) })\end{array}$ & $\begin{array}{c}\text { Straw yield } \\
\text { (t/fed) }\end{array}$ & $\begin{array}{c}\text { Grain yield } \\
\text { (ardab/fed) }\end{array}$ \\
\hline Residue : & $* *$ & $* *$ & $*$ & NS & NS & $* *$ & $* *$ & $* *$ \\
Control & $92.9 \mathrm{~b}$ & $159.2 \mathrm{c}$ & $9.3 \mathrm{~b}$ & 21.0 & 42.9 & $48.94 \mathrm{~b}$ & $3.13 \mathrm{c}$ & $9.35 \mathrm{c}$ \\
Herbicide & $100.6 \mathrm{a}$ & $329.4 \mathrm{ab}$ & $10.7 \mathrm{a}$ & 21.5 & 49.5 & $50.73 \mathrm{a}$ & $3.34 \mathrm{c}$ & $17.58 \mathrm{a}$ \\
Roots (R) & $102.8 \mathrm{a}$ & $366.6 \mathrm{a}$ & $10.7 \mathrm{a}$ & 21.5 & 50.9 & $51.89 \mathrm{a}$ & $4.32 \mathrm{a}$ & $16.54 \mathrm{a}$ \\
Stems (S) & $101.1 \mathrm{a}$ & $272.0 \mathrm{~b}$ & $10.4 \mathrm{a}$ & 21.1 & 50.3 & $51.59 \mathrm{a}$ & $3.43 \mathrm{c}$ & $15.31 \mathrm{~b}$ \\
$\mathbf{R}+\mathbf{S}$ & $101.2 \mathrm{a}$ & $329.2 \mathrm{ab}$ & $10.8 \mathrm{a}$ & 21.7 & 50.8 & $50.99 \mathrm{a}$ & $3.86 \mathrm{~b}$ & $16.41 \mathrm{a}$ \\
\hline Kg N/fed. : & $* *$ & $*$ & $*$ & $\mathrm{NS}$ & $*$ & $* *$ & $*$ & $* *$ \\
$\mathbf{6 5}$ & $97.6 \mathrm{~b}$ & $250.4 \mathrm{~b}$ & $9.9 \mathrm{~b}$ & 21.1 & $46.0 \mathrm{~b}$ & $48.58 \mathrm{c}$ & $3.16 \mathrm{~b}$ & $13.03 \mathrm{~b}$ \\
$\mathbf{7 5}$ & $99.0 \mathrm{ab}$ & $301.9 \mathrm{a}$ & $10.4 \mathrm{ab}$ & 21.4 & $48.4 \mathrm{ab}$ & $51.47 \mathrm{~b}$ & $3.78 \mathrm{a}$. & $15.27 \mathrm{a}$ \\
$\mathbf{8 5}$ & $102.6 \mathrm{a}$ & $307.2 \mathrm{a}$ & $10.8 \mathrm{a}$ & 21.6 & $52.0 \mathrm{a}$ & $52.44 \mathrm{a}$ & $3.98 \mathrm{a}$ & $16.45 \mathrm{a}$ \\
\hline Interaction: & $\mathrm{NS}$ & $*$ & $\mathrm{NS}$ & $\mathrm{NS}$ & $\mathrm{NS}$ & $* *$ & $\mathrm{NS}$ & $* *$ \\
\hline
\end{tabular}

$*^{*}, *$ and NS indicate $\mathrm{p}<0.05, \mathrm{p}<0.01$ and not significant, respectively. Means of each factor designated by the same letters are not significantly different at $5 \%$ level, using Duncan's multiple range test.

Table (8): Plant height, straw yield, grain yield and its attributes of wheat as affected by sunflower residues and nitrogen rates in 2014 / 2015 season.

\begin{tabular}{|c|c|c|c|c|c|c|c|c|}
\hline Factor & $\begin{array}{c}\text { Plant } \\
\text { height }(\mathbf{c m})\end{array}$ & $\begin{array}{c}\text { No. of } \\
\text { spikes/m } \mathbf{2}\end{array}$ & $\begin{array}{c}\text { Spike } \\
\text { length } \\
(\mathbf{c m})\end{array}$ & $\begin{array}{c}\text { No. of } \\
\text { spikelets/ } \\
\text { spike }\end{array}$ & $\begin{array}{c}\text { No. of grains } \\
\text { /spike }\end{array}$ & $\begin{array}{c}\text { 1000-grain } \\
\text { weight (g) }\end{array}$ & $\begin{array}{c}\text { Straw yield } \\
(\mathbf{t} / \mathbf{f e d})\end{array}$ & $\begin{array}{c}\text { Grain yield } \\
\text { (ardab/fed) }\end{array}$ \\
\hline Residue : & $*$ & $*$ & $* *$ & $*$ & $* *$ & $* *$ & $* *$ & $* *$ \\
\hline Control & $91.0 \mathrm{~b}$ & $245.8 \mathrm{~b}$ & $9.7 \mathrm{~b}$ & $20.4 \mathrm{~b}$ & $51.6 \mathrm{~b}$ & $46.60 \mathrm{c}$ & $3.35 \mathrm{c}$ & $10.60 \mathrm{c}$ \\
\hline Herbicide & $97.8 \mathrm{a}$ & $356.2 \mathrm{a}$ & $10.7 \mathrm{a}$ & $20.7 \mathrm{ab}$ & $56.2 \mathrm{ab}$ & $48.65 \mathrm{~b}$ & $4.31 \mathrm{ab}$ & $18.73 \mathrm{a}$ \\
\hline Roots (R) & $102.9 \mathrm{a}$ & $342.9 \mathrm{a}$ & $10.6 \mathrm{a}$ & $21.2 \mathrm{a}$ & $58.4 \mathrm{a}$ & $50.86 \mathrm{a}$ & $4.23 \mathrm{ab}$ & $18.77 \mathrm{a}$ \\
\hline Stems (S) & $98.4 \mathrm{a}$ & $330.3 \mathrm{a}$ & $10.7 \mathrm{a}$ & $20.9 \mathrm{ab}$ & $56.5 \mathrm{ab}$ & $50.62 \mathrm{a}$ & $3.78 \mathrm{be}$ & $16.42 \mathrm{~b}$ \\
\hline $\mathbf{R}+\mathbf{S}$ & $99.9 \mathrm{a}$ & $353.3 \mathrm{a}$ & $10.6 \mathrm{a}$ & $21.0 \mathrm{a}$ & $59.4 \mathrm{a}$ & $51.38 \mathrm{a}$ & $4.50 \mathrm{a}$ & $17.68 \mathrm{a}$ \\
\hline Kg N/fed: & $*$ & $*$ & $\mathrm{NS}$ & $*$ & $\mathrm{NS}$ & $\mathrm{NS}$ & $*$ & $* *$ \\
\hline $\mathbf{6 5}$ & $94.7 \mathrm{~b}$ & $304.4 \mathrm{~b}$ & 10.3 & $20.3 \mathrm{~b}$ & 55.3 & 49.20 & $3.54 \mathrm{~b}$ & $15.32 \mathrm{c}$ \\
\hline $\mathbf{7 5}$ & $98.3 \mathrm{ab}$ & $335.6 \mathrm{a}$ & 10.5 & $21.1 \mathrm{a}$ & 56.2 & 50.66 & $4.10 \mathrm{a}$ & $16.46 \mathrm{~b}$ \\
\hline $\mathbf{8 5}$ & $101.0 \mathrm{a}$ & $336.6 \mathrm{a}$ & 10.7 & $21.1 \mathrm{a}$ & 57.8 & 50.80 & $4.43 \mathrm{a}$ & $16.54 \mathrm{a}$ \\
\hline Interaction & $\mathrm{NS}$ & $\mathrm{NS}$ & $\mathrm{NS}$ & $\mathrm{NS}$ & $\mathrm{NS}$ & $\mathrm{NS}$ & $\mathrm{NS}$ & $\mathrm{NS}$ \\
\hline
\end{tabular}

$*$, ** and NS indicate $\mathrm{p}<0.05, \mathrm{p}<0.01$ and not significant, respectively. Means of each factor designated by the same letters are not significantly different at 5\% level, using Duncan's multiple range test. 
received 60 or $90 \mathrm{~kg} \mathrm{~N} / \mathrm{fed}$. Wheat plants receiving 75 or $85 \mathrm{~kg} \mathrm{~N} / \mathrm{fed}$ produced significantly higher number of spikes/m2, number of spikelets/spike as well as straw and grain yields/fed than those received $65 \mathrm{~kg}$ $\mathrm{N} / \mathrm{fed}$ in the two seasons. With respect to 1000 grain weight in the first season and grain yield/fed in the second season, a significant increase accompanied each increment of applied nitrogen. Grain yield is a final indicator of crop behavior under different crop management practices. The increase in plant height, grain yield and its attributes, with increasing nitrogen rate, was possibly due to the absorption of more nutrients from the soil, which promoted the growth of wheat. Nitrogen rate increased grain yield through increasing the number of spikes $/ \mathrm{m}^{2}$, number of spikelets and grains/spike and 1000 grain weight. Moreover, growth in terms of LAI, DM and CGR were in favor of nitrogen additions and this was reflected on increasing different yield attributes. A positive association between nitrogen fertilization and grain yield and its attributes has been reported by Said (1998) and Sharshar (2000).

The interaction between sunflower residues and nitrogen rates had a significant effect on the number of spikes $/ \mathrm{m}^{2}$, I 000-grain weight and grain yield of wheat/fed. in the first season, only (Tables 7 and 8).

3.2. Interaction between sunflower residues and nitrogen levels.

Data in (Table 9) indicated that soil incorporation of sunflower residues and herbicide treatment significantly increased the number of spikes $/ \mathrm{m}^{2}$, compared to the control at the same nitrogen rate. The highest number of spikes $/ \mathrm{m}^{2}$ resulted from herbicide, sunflower $(\mathrm{R})$ and $(\mathrm{R}+\mathrm{S})$ at the rates of 75 or $85 \mathrm{~kg} \mathrm{~N} /$ fed Data also, showed that soil incorporation of sunflower $(\mathrm{R}+\mathrm{S})$ at $85 \mathrm{~kg}$ $\mathrm{N} /$ fed produced the highest 1000-grain weight $(51.35 \mathrm{~g})$. Herbicide and sunflower (R) and (S) treatments at 75 or $85 \mathrm{~kg} \mathrm{~N} / \mathrm{fed}$, did not significantly differ from the mentioned treatment in this respect (Table 9). At the same nitrogen rate, sunflower residues and herbicide treatment significantly increased grain yield, compared to the control. Soil incorporation of sunflower $\mathrm{R}$ at $85 \mathrm{~kg} \mathrm{~N} / \mathrm{fed}$ produced the highest grain yield/fed without significant difference with herbicide treatment or $\mathrm{R}$ at $75 \mathrm{~kg} \mathrm{~N} / \mathrm{fed}$, as well as with herbicide treatment or $(\mathrm{R}+\mathrm{S})$ at $85 \mathrm{~kg} \mathrm{~N} / \mathrm{fed}$.

Table (9): Number of spikes/ $\mathrm{m} 2,1000$-grain weight and grain yield of wheat/ fed as affected by the interaction between sunflower residues and nitrogen rates in 2013 / 2014 season.

\begin{tabular}{|c|c|c|c|c|c|}
\hline \multirow{2}{*}{$\begin{array}{c}\text { Kg } \\
\text { N/fed }\end{array}$} & \multicolumn{5}{|c|}{ Residues } \\
\cline { 2 - 6 } & Control & Herbicide & Roots (R) & Stems (S) & $(\mathbf{R}+\mathbf{S})$ \\
\hline \multirow{3}{*}{$\mathbf{6 5}$} & \multicolumn{5}{|c|}{ Number of spikes/ m } \\
\cline { 2 - 6 } $\mathbf{7 5}$ & $145.0 \mathrm{~d}$ & $261.0 \mathrm{c}$ & $367.4 \mathrm{a}$ & $235.0 \mathrm{c}$ & $243.5 \mathrm{c}$ \\
$\mathbf{8 5}$ & $159.7 \mathrm{~d}$ & $342.8 \mathrm{ab}$ & $351.0 \mathrm{a}$ & $278.4 \mathrm{c}$ & $377.6 \mathrm{a}$ \\
& $158.0 \mathrm{~d}$ & $369.5 \mathrm{a}$ & $366.3 \mathrm{a}$ & $299.5 \mathrm{be}$ & $351.6 \mathrm{a}$ \\
\cline { 2 - 6 } $\mathbf{6 5}$ & $44.11 \mathrm{e}$ & $46.68 \mathrm{~d}$ & $48.99 \mathrm{~cd}$ & $47.86 \mathrm{~d}$ & $51.25 \mathrm{~cd}$ \\
$\mathbf{7 5}$ & $48.28 \mathrm{bed}$ & $50.23 \mathrm{abc}$ & $51.35 \mathrm{ab}$ & $52.12 \mathrm{a}$ & $52.38 \mathrm{bed}$ \\
$\mathbf{8 5}$ & $49.43 \mathrm{bed}$ & $51.29 \mathrm{ab}$ & $53.32 \mathrm{a}$ & $52.81 \mathrm{a}$ & $51.32 \mathrm{a}$ \\
\cline { 2 - 6 } & \multicolumn{5}{|c|}{ Grain yield of wheat (ardab/fed) } \\
\cline { 2 - 6 } $\mathbf{6 5}$ & $8.55 \mathrm{~g}$ & $15.34 \mathrm{c}-\mathrm{f}$ & $14.26 \mathrm{def}$ & $14.29 \mathrm{ef}$ & $14.38 \mathrm{f}$ \\
$\mathbf{7 5}$ & $9.48 \mathrm{~g}$ & $17.69 \mathrm{ab}$ & $17.65 \mathrm{abc}$ & $15.23 \mathrm{def}$ & $16.43 \mathrm{~b}-\mathrm{e}$ \\
$\mathbf{8 5}$ & $9.39 \mathrm{~g}$ & $18.70 \mathrm{ab}$ & $18.81 \mathrm{a}$ & $16.49 \mathrm{bed}$ & $17.66 \mathrm{ab}$ \\
\hline
\end{tabular}




\section{Conclusion}

It can be concluded that soil incorporation of sunflower roots with $75 \mathrm{~kg}$ $\mathrm{N} /$ fed could be recommended for optimum wheat grain yield under the environmental condition of this study, in addition to minimizing the environmental pollution caused by herbicides.

\section{REFERENCES}

Altieri A. M. and Liebman M. (1998). Weed Management in Agroecosystems Ecological Approaches. Florida: CRC Press,

Azania A. A. P. M., Azania C. A. M., Alves P. L. C. A., Palaniraj R., Kadian H. S., Sati S. C., Rawat L. S., Dahiya D. S. and Narwal S.S. ( 2003). Allelopathic plants, sunflower (Helianthus annuus L.). Allelopathy J., 11: (1): 1-20.

Castillo R. (2005). Allelopathic potentials of maize, sorghum and sunflower for weed control. Fitosanidad. 9: 3, 23-26.

Duck S.O. (1985). Biosynthesis of phenolic compounds-chemical manipulation in higher plants. The chemistry of allelopathy: Biochemical interactions among plants, (Ed.A.C.Thampson)., $113-131$.

Duncan D. B. (1955). Multiple range and multiple F-tests. Biometrics, 11: 1-42.

Gomez K. A. and Gomez A. A.(1984). Statistical Procedures for Agricultural Research. John Willey and Sons Inc., New York., USA.

Kaczmarek S. (2009). Using of the allelechemical potential in selected agricultural crops. Progress in Plant Protection. 49: 3, 1502-1511.

Latiri S. K., Nortcliff S. and Lawlor D.W. ( 1998). Nitrogen fertilizer can increase dry matter, grain production and radiation and water use efficiencies for durum wheat under semi-arid conditions. European J. of Agronomy, 9 (1): 21-34.

Mahmood R., Khaliq A. and Hassan S. (2010). Evaluating the potential of allelopathic plant water extracts in suppressing horse purslane growth.
Inter. J. Agric. and Biol. 12: 4, 581585.

Mehboob N., Saleem B. and Qureshi M. J. (2000). Allelopathic influence of sunflower (Helianthus annuus) on germination and seedling growth of linseed (Linum usitatissimum). Pakistan J. of Biological Sci., 3 (8): 13051307.

Muhammad J., Cheema Z. A., Mushtaq M. N., Farooq M. and Cheema M. A. (2009). Alternative control of wild oat and canary grass in wheat fields by allelopathic plant water extracts. Agron. for Sust. Develop., 29 (3): 475482

Mushtaq M. N., Cheema Z. A., Abdul Khaliq and Naveed M. R. ( 2010). A $75 \%$ reduction in herbicide use through integration with sorghum + sunflower extracts for weed management in wheat. J. Sci. Food and Agric.; 90 : 11, 1897-1904.

Naseem M. (1997). Allelopathic effects of autumn sunflower residues on wheat productivity and wheat weeds . Ph. D. Thesis, Dept. of Agron., Univ. of Agric. ,Faisalabad, Pakistan.

Park K. H. and Moody K. (1991). Allelopathic activity and identification of allelochemicals of sunflower (Helianthus annuus L.). Philipp. J. Weed Sci., 18: 25-40.

Said S. M. H. (1998). Effect of some cultural practices on wheat production. M.Sc. Thesis, Fac. of Agric., Al-Azhar Univ.,Cairo, Egypt.

Sharshar M. S., Sobh M. M. and Sherif Fatma A. (2000). Effect of some Nbiofertilizer sources as supplementary fertilization on wheat yield, yield components and quality under graded levels of $\mathrm{N}$-chemical fertilizer. J. Product. \& Dev., 5 (1): 1-11

Sorour F. A., Mosalem M. E. and Khaffagy Azza.E. (1998). Effect of preceding crop, seeding rates and nitrogen levels on wheat growth and yield and its components. J. Agric. Res., Tanta Univ., Egypt, 24(3):263-281.

Tehmina A. and Rukhsana B.(2007). The effect of sunflower leaf extracts on 
Chenopodium album in wheat fields in

Pakistan. Crop Protec.,26: (9): 13901394.
Watson D.I. ( 1952). The physiological basis of variation in yield.Adv.in Agron., 4: 101-144.

تأثير بقايا دوار الشمس تحت مستويات مختلفة من النيتروجين على محصول القمح و الحشائش المصاحبة له له

إبراهيم السيد سليمان ـ أمانى محمود حمزة*

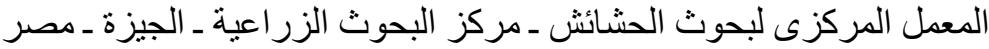

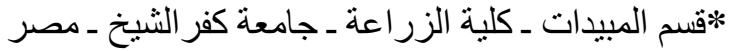

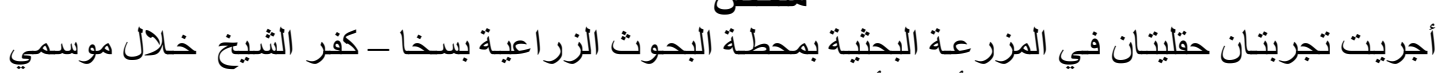

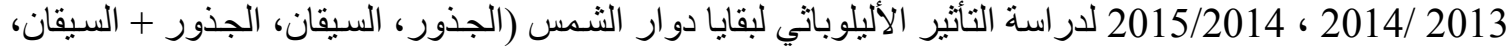

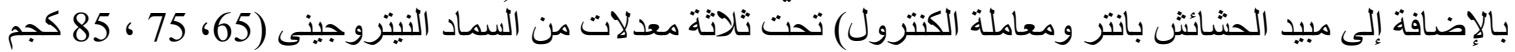

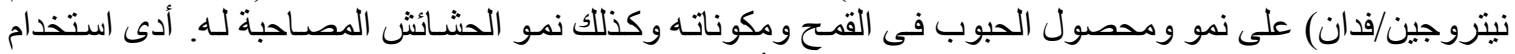

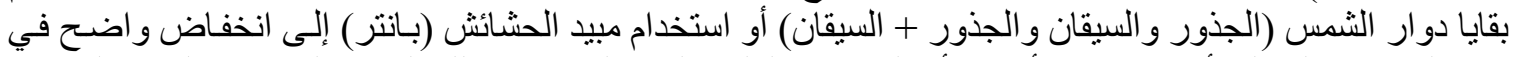

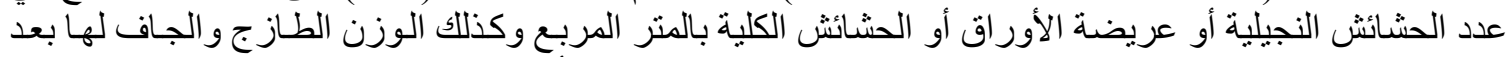

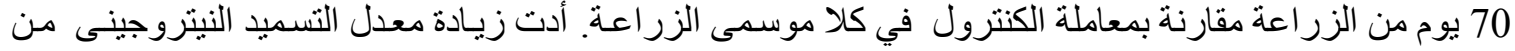

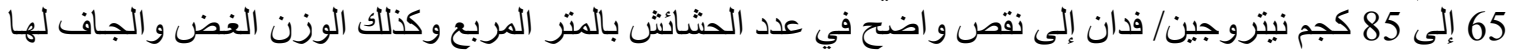

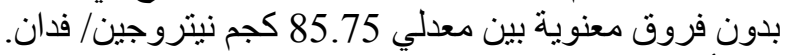

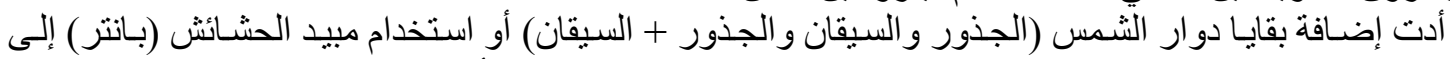

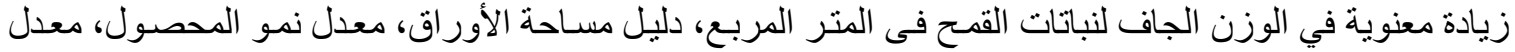

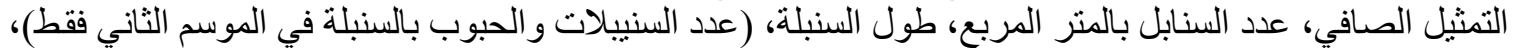

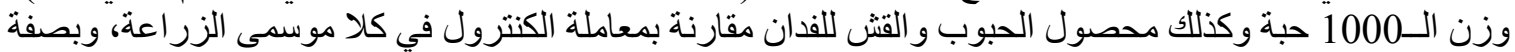

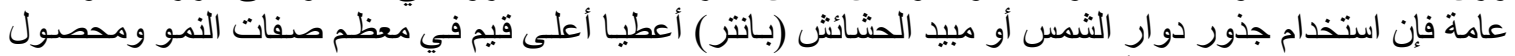

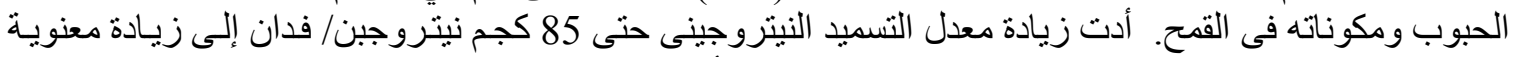

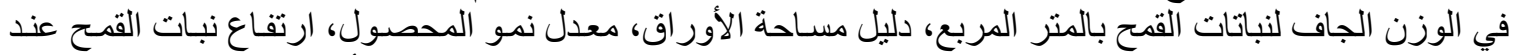

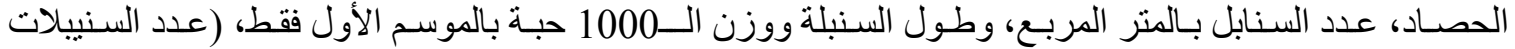

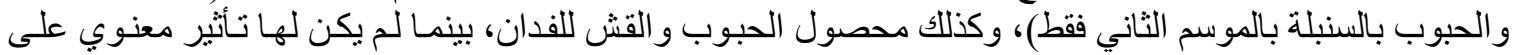

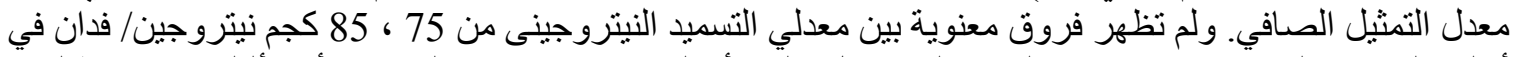

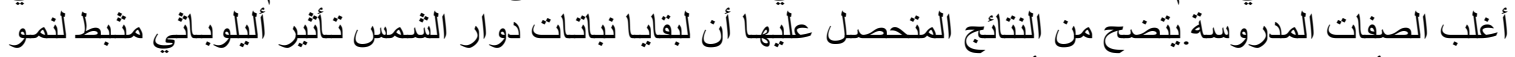

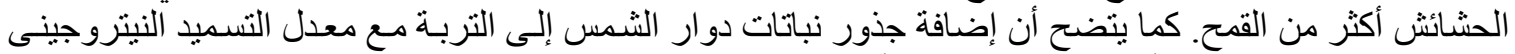

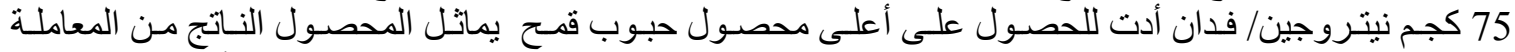

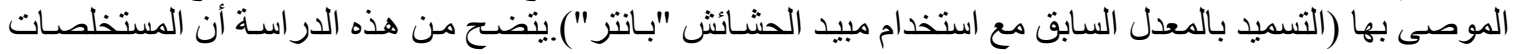

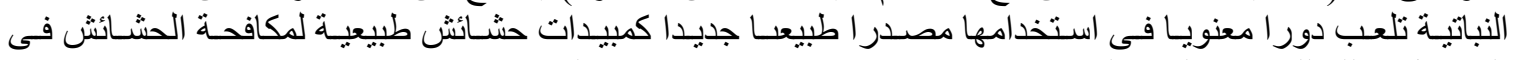

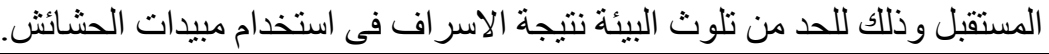

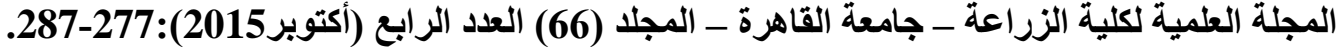

